\title{
Spotted Cats in Latin America: an Interim Report
}

Dr Karl B. Koford spent seven months last year studying the status and distribution of the spotted cats, especially jaguar and ocelot, in tropical America from Mexico south to Brazil and Argentina. This project, to which FPS contributed through the Oryx 100\% Fund, is mainly funded by the International Fur Trade Federation (as part of the agreement in December 1970 that introduced a voluntary ban on the use of five endangered fur species, including leopards and the cheetah), the Frankfurt Zoological Society and WWF. The following is taken from Dr Koford's 'interim conservation review'his final report will come later this year-together with some points from his separate reports on ten Latin American countries.

Jaguar Felis onca-the largest Neotropical carnivore, has declined in area and numbers in all countries, especially during the last fifteen years. They could well be exterminated in this decade in Mexico and Argentina; in the latter where their habitat has been destroyed Dr Koford estimates the population as low as 100 . Nocturnal and solitary, they disappear rapidly when primitive areas are opened up by roads and settlements, which is what is happening in the Amazon forest where most of the remaining animals survive. Moreover, they probably require over $100 \mathrm{sq} \mathrm{km} \mathrm{(40} \mathrm{sq} \mathrm{miles)} \mathrm{per}$ adult, so few reserves in Latin America are large enough to protect normal populations of jaguars, and none are adequately patrolled against hunters, though a few huge fazendas (ranches) maintain limited numbers and often give them better protection than the official reserves. The high market price of pelts has tended to divert ranchers to hunting, an occupation of lower national value. Inasmuch as jaguars are scarce and difficult game for individual campesinos (peasant farmers), the high price of skins principally benefits teams of commercial hunters. The fact that Colombia still permits commerce in jaguar pelts-apparently the only Latin American country that still does so (Paraguay was scheduled to stop August $31 \mathrm{st}$ ) encourages smuggling, which would be inhibited by lower market prices. One alarming trend is the introduction of steel traps, some possibly even by missionaries, in Paraguay and Colombia.

Ocelots $F$. pardalis, also nocturnal and secretive, have become rare where heavily hunted, as along rivers and roads and near towns, and where forest and scrub have been essentially replaced by grasslands and crops. But populations survive in a wide variety of habitats including spiny semi-arid brlushlands, estuarine mangroves, swamp forests, wooded hills, cutover forests, and other kinds of dense cover as well as in typical jaguar habitats-humid forests and savannas. Inasmuch as only a shotgun or trap is needed to hunt ocelots and the 
value of pelts is high (about half that of jaguar), they are a valuable resource to Indians and campesinos from Yucatan to the Chaco. It can be argued that where habitats are being completely destroyed, as by flooding or planting with cotton, the native wildlife will be lost in any event, so why not harvest it? Although there has yet been no intensive field study of an ocelot population, the species seems to have broad ecological requirements and can probably sustain moderate hunting pressure. A controlled annual harvest may prove feasible on lands of little agricultural value, as in the Chaco of Paraguay.

The high traffic in ocelot skins from 1968 to 1970 may have represented, in large part, the hunting of the most accessible sites under stimulus of high demand. That peak is past, and new restrictions in several countries will further reduce the take. (Unfortunately, they will also cut off further statistics on numbers and areas of origin.) From 1968 to 1972, prices to hunters remained about the same in most areas and decreased in some. From the biological standpoint, it is not certain that a reduction in the export market is necessary at this time to conserve the species, but other reasons for reducing the trade are:

1. To reduce law enforcement problems by reducing hunting pressure and movement of contraband skins;

2. To protect other kinds of spotted cats, not easily distinguished in the field;

3. To reduce the drain of agricultural workers becoming skin hunters;

4. To reduce danger to people, livestock, and legitimate game from night hunters.

Margary $F$. wiedii and Tiger cat $F$. Tigrina are rare in most areas, common in none, yet, according to IUCN, Dr J. Carvalho in 1971 counted some 56,000 margay and 28,000 tiger-cat skins in Brazilian warehouses. These two species constitute only about a fifth of the trade in tigrillos (a name that covers all small cats), and the value of their pelts is a fraction of the ocelots. Their habits are poorly known to science. The margay, because it is more arboreal than the ocelot, probably suffers more from deforestation; the tiger cat apparently favours subtropical forests, which have been largely destroyed to grow coffee. The proportion of these small cats exported could be reduced by the enforcement of a minimum size. The tiger cat may be a valuable source of income to campesinos of north-eastern Brazil; otherwise there seems no justification for hunting these small cats.

Geoffrey's cat $F$. geoffroyi is fairly common from the steppes of central Argentina to the savannas of Uruguay and the thorny mata of the Chaco. A versatile animal, it feeds both in trees and on the ground, and moderate deforestation seems to have little effect on it. Argentina and Uruguay utilise many more of these pelts than they export, and the Chaco Indians derive considerable income from them. There is no need for strong conservation measures for it.

In general, known exports of spotted cats dropped after 1969, 
perhaps partly because accessible populations had been depleted, but also because of new conservation restrictions: Argentina, Peru and Venezuela prohibited the taking of jaguars; Brazil banned all trade in wildlife; Ecuador prohibited the taking of tiger cats and ocelots, and a moratorium on all wildlife exports is expected; Colombia stopped the export of untanned wildlife skins, and the USA listed jaguars, ocelots, margays and tiger cats as endangered and thereby banned all imports. All these measures are welcome though they have probably led to an increase in smuggling and certainly reduced the statistics.

If all countries involved could have uniform legislation and cooperative enforcement agreements this would reduce some of the smuggling. IUCN also urges the necessity of further field studies because so little is known about the requirements of these cats, the establishment of large reserves, and encouragement to landowners to protect the cats on their land. Most important of all, and the object of Dr Koford's survey, is to establish which species are certainly endangered and get all trade in them banned.

\section{Brazil's Endangered Fauna}

The Brazil Academy of Sciences, in Rio de Janeiro, has published Especies da Fauna Brasileira Ameaçadas de Extinçao (Species of Brazilian Fauna in Danger of Extinction). It represents a milestone in Latin American conservation. It is the result of the Technical Meeting in Rio de Janeiro, in October 1971, organised by the Academy (Academia Brasileira de Ciências), the National Research Council (Conselho Nacional de Pesquisas), the Forestry Development Institute (Instituto Brasileiro de Desenvolvimento Florestal) and the major Brazilian conservation organisations. Unfortunately no English translation is available.

In the first chapter, 'Conservation and Extinction', Fernando Dias de Avila-Pires deals primarily with ecology, hazards of misuse of the environment and the need for rational use of resources. The next two chapters, on mammals and birds, which make up the bulk of the book, are undoubtedly the most useful contributions. Adelmar F. Coimbra-Filho discusses in detail the 25 Brazilian mammals now recognized as endangered (including three forms not mentioned in the Red Data Book: the buffheaded marmoset Callithrix jacchus flaviceps, a southern subspecies of the Jaguar Panthera onca palustris and the southern representative of the giant otter Pteronura brasiliensis paranaensis). A description of each animal is given and distribution, present status, reproductive potential in captivity and protective measures already taken are discussed. Helmut Sick reviews the factors threatening Brazil's bird fauna and discusses briefly each of the 40 endangered species, pointing out that the Red Data Book on birds, which lists only four Brazilian species, is 'very incomplete as far as South American birds are concerned'.

Conservation problems of reptiles and amphibians, fish and invertebrates are briefly reviewed in three chapters by Paulo E. Vanzolini, A. Britski and J. L. de Figueiredo, and José Candido de Melo Carvalho respectively; finally Alceo Magnanini describes the Brazilian National Parks and Federal Biological Reserves and lists the endangered mammals and birds in each.

All in all, this nicely produced little book represents quite a conservation achievement for Brazil and should set the groundwork for future conservation. Brazil's example will hopefully be followed in the rest of Latin America. 